\title{
CRITICAL THINKING DEVELOPMENT TECHNOLOGY: THEORETICAL BASIS AND ITS APPLICATION IN SECONDARY SCHOOL (TO TEACHING THE RUSSIAN LANGUAGE)
}

\author{
TECNOLOGIA DO DESENVOLVIMENTO DO PENSAMENTO CRÍTICO: \\ FUNDAMENTOS TEÓRICOS E APLICAÇÃO NA ESCOLA SECUNDÁRIA (AO \\ ENSINO DA LÍNGUA RUSSA)
}

\author{
TECNOLOGÍA DE DESARROLLO DEL PENSAMIENTO CRÍTICO: FUNDAMENTOS \\ TEÓRICOS Y APLICACIÓN EN LA ESCUELA SECUNDARIA (SOBRE EL EJEMPLO \\ DE LA ENSEÑANZA DE LA LENGUA RUSA)
}

\author{
Ekaterina Gennadievna SHTYRLINA ${ }^{1}$ \\ Aida Marsovna KAZANTSEVA ${ }^{2}$ \\ Izanloo $\mathrm{HASAN}^{3}$
}

\begin{abstract}
The paper presents a modern pedagogical technology for the critical thinking development, aimed at forming the pupils' ability to analyze facts, phenomena, and processes from the standpoint of logic in their relationship and interdependence. It reveals the specifics of critical thinking development technology, provides a description of the methodology for critical thinking development using the example of teaching the Russian language at high school: the stages of the educational process (challenge, comprehension, reflection), techniques and methods of this technology, examples of their application and advantages of use. In course of the study, the authors conclude that the critical thinking development technology is implemented through the interactive inclusion of students in the educational space through a specific organization of the educational process based on three main stages and a system of teaching methods that consistently implement the tasks at each stage. The critical thinking development technology activates the pupils' mental and speech activity and contributes to their active involvement in the educational and cognitive process. The study is based on the methods of observation, analysis, synthesis, description, comparison, and generalization.
\end{abstract}

KEYWORDS: Critical thinking. Technology. Technological stages. Teaching methods and strategies. Teaching the Russian language.

RESUMO: O artigo apresenta uma tecnologia pedagógica moderna para o desenvolvimento do pensamento crítico, que visa formar a capacidade dos alunos de analisar fatos, fenômenos e processos do ponto de vista da lógica em sua relação e interdependência. Ele revela as

\footnotetext{
${ }^{1}$ Kazan Federal University (KPFU), Kazan - Russia. Associate Professor of the Department of Russian as a Foreign Language, Institute of Philology and Intercultural Communication. PhD in Philology. ORCID: https://orcid.org/0000-0001-7112-3380. E-mail: shtyrlinaekaterina@gmail.com

${ }^{2}$ Kazan Federal University (KPFU), Kazan - Russia. Senior Lecturer at the Department of Russian as a Foreign Language, Institute of Philology and Intercultural Communication. $\mathrm{PhD}$ in Philology. ORCID: https://orcid.org/0000-0002-8994-2779. E-mail: aida.kazanceva@mail.ru

${ }^{3}$ Ferdowsi University of Mashhad, Mashhad - Iran. Associate Professor of the Department of Russian Language. ORCID: https://orcid.org/0000-0003-4340-2483.E-mail: izanloo@yadex.ru
}

Rev. EntreLínguas, Araraquara, v. 7, n. esp. 1, p. 31-38, fev. 2021. 
especificidades da tecnologia de desenvolvimento do pensamento crítico, fornece uma descrição da metodologia para o desenvolvimento do pensamento crítico usando o exemplo do ensino da língua russa no ensino médio: as etapas do processo educacional (desafio, compreensão, reflexão), técnicas e métodos de esta tecnologia, exemplos de sua aplicação e vantagens de uso. No decorrer do estudo, os autores concluem que a tecnologia de desenvolvimento do pensamento crítico é implementada por meio da inclusão interativa dos alunos no espaço educacional por meio de uma organização específica do processo educacional com base em três etapas principais e um sistema de métodos de ensino que implementam consistentemente as tarefas de cada estágio. A tecnologia de desenvolvimento de pensamento crítico ativa a atividade mental e de fala dos alunos e contribui para seu envolvimento ativo no processo educacional e cognitivo. $O$ estudo é baseado nos métodos de observação, análise, síntese, descrição, comparação e generalização.

PALAVRAS-CHAVE: Pensamento crítico. Tecnologia. Etapas tecnológicas. Métodos e estratégias de ensino. Ensino da língua russa.

RESUMEN: El artículo presenta una moderna tecnología pedagógica para el desarrollo del pensamiento crítico, orientada a formar la capacidad de los alumnos para analizar hechos, fenómenos y procesos desde el punto de vista de la lógica en su relación e interdependencia. Revela los detalles de la tecnología de desarrollo del pensamiento crítico, proporciona una descripción de la metodología para el desarrollo del pensamiento crítico utilizando el ejemplo de la enseñanza del idioma ruso en la escuela secundaria: las etapas del proceso educativo (desafio, comprensión, reflexión), técnicas y métodos de esta tecnología, ejemplos de su aplicación y ventajas de uso. En el transcurso del estudio, los autores concluyen que la tecnología de desarrollo del pensamiento crítico se implementa a través de la inclusión interactiva de los estudiantes en el espacio educativo a través de una organización específica del proceso educativo basado en tres etapas principales y un sistema de métodos de enseñanza que implementan consistentemente la tareas en cada etapa. La tecnología de desarrollo del pensamiento crítico activa la actividad mental y del habla de los alumnos y contribuye a su participación activa en el proceso educativo y cognitivo. El estudio se basa en los métodos de observación, análisis, síntesis, descripción, comparación y generalización.

PALABRAS CLAVE: Pensamiento crítico. Tecnologia. Etapas tecnológicas. Métodos y estrategias de enseñanza. Enseñanza del idioma ruso.

\section{Introduction}

Recently, great changes have been taking place in the field of education: the educational system itself is being reformed, new requirements for the teaching profession are being put forward, teaching methods and tactics are being modernized (NURULLINA; EROFEEVA; USMANOVA, 2018; EROFEEVA et al., 2019). New requirements aligned with the national educational initiative "Our New School" entail the introduction of innovative methods in education, focused both on gaining knowledge, the formation and development of cognitive interests and abilities, creative thinking, independent brain work abilities and skills 
(BOCHINA; AGEEVA; VLASICHEVA, 2014; SHKURKO; LUKOYANOVA; SERGEEVA, 2017).

With this approach, "the central figure in an educational institution, its core should be the student $<\ldots>$ viewed not abstractly, not as a class, group or the entire educational institution, but at the individual level in all his wealth and diversity of his personal interests, needs, and aspirations" (BELOZERTSEV; CHERNYKH, 2003, p. 307). Such a pupil must become the subject of the educational process, strive not only to obtain the knowledge communicated by the teacher, but also to be able to independently obtain and use it in life.

The above tasks can be implemented by the introduction of developing techniques in the secondary school educational process, one of which is the development of critical thinking, aimed at mastering creative ways of solving life problems, self-education, and selfimprovement by pupils. The conceptual idea of this pedagogical technique is "the formation of the pupil's position as the subject of his own educational and cognitive activity, the ability to reflect on it, organize, implement, independently achieve the goals set" (GALITSKY, 2004, p. 112). The teacher's role in this case is considered primarily through the prism of managing the independent cognitive activity of the pupils.

\section{Materials and methods}

During the study, the following general scientific methods were used: methods of observation, analysis and synthesis, descriptions, comparisons, generalizations.

\section{Results and discussion}

The critical thinking development technology is a combination of strategies and techniques aimed at developing the pupils' ability to analyze facts, phenomena and processes from the standpoint of logic, in their relationship and interdependence: "Critical thinking involves the skills of reflection on one's own mental activity, the ability to work with concepts, judgments, conclusions, questions, developing analytic ability, and the ability to evaluate the similar capabilities in other people" (SORINA, 2003, p. 101).

The use of the critical thinking technology in secondary school educational process will contribute to the intensification of independent search of creative work of pupils, the formation of intellectual skills aimed at solving educational, scientific, and practical tasks (goal-setting, 
problem identification, hypothesizing, argumentation and rational, informed decision making, reflecting on one's own mental activity), self-organization and self-education skills.

The technology for the development of critical thinking requires the interaction of a teacher and a student using special pedagogical tools, the correct choice of forms and methods of training organization, and the compliance with certain pedagogical conditions. It should be noted that classes based on in critical thinking, a subject-subject relationship is built up between the teacher and the pupils, which is underlain by a mutual aspiration of the participants of the educational environment for collaborative activity. The participants of the educational process are united by the common goal of the lesson, a collective creative search to solve tasks (NIKIFOROVA; BORISOVA; EVERSTOVA, 2017).

The pedagogical critical thinking development technology is based on a class model consisted of three stages:

- challenge or motivation;

- comprehension of the content or realization of the meaning;

- reflection or thinking (ZAGASHEV; ZAIRE-BEK, 2003).

These stages are the technological basis for the development of critical thinking, allowing learners to independently determine learning goals, carry out an active search for information and reflect on what they have learned.

Each of the above stages of the basic lesson model has a certain set of methodological techniques, first aimed at enhancing research, creative activity, and then comprehending and generalizing the acquired knowledge:

- a predictions tree, thin and thick questions, brainstorming, a basket of ideas, etc. (the challenge stage),

- text marking, logbook, insert, Bloom cube, etc. (the comprehension stage),

- marking table, cluster, conceptual table, essays, etc. (the reflection stage).

Thus, the basic technology model defines not only a certain logic for constructing a training lesson, but also a sequence and methods of combining specific teaching methods.

The first stage, Challenge, is aimed at involving pupils in education, at awakening their interest in the topic being studied, to revising the existing knowledge and determining the areas for further study. At this stage, using various techniques (forecasting the content; brainstorming; problematic issues, etc.), the teacher invites the students to learn a new topic. 
The teacher can organize work in mini-groups, in pairs or suggest that the children work independently, individually. The pupils are required to tell everything that they know about the issue under consideration and reflect on what is still unknown to them and on what they would like to know. Therefore, the pupils independently formulate their own goals and motives for studying the new material.

An example of the application of critical thinking technology at the Challenge stage is the use of the true/false technique in school practice of teaching the Russian language. At the beginning of the lesson, the teacher offers a series of statements on a topic that has not yet been studied, among which the pupils are supposed to choose the true ones and substantiate their choice. For example, when studying synonyms, the pupils may be offered the following statements for consideration: 1) Synonyms are words that differ in sound and spelling, but have the same or very close lexical meaning, 2) Synonyms are the words belonging to the same part of speech, 3) Synonyms are completely identical in meaning, 4) Synonyms cannot differ in stylistic nuance, 5) Synonyms are used to highlight semantic nuances and to increase the imagery and the artistic visualization of speech. This methodological technique allows the pupils early in the lesson to clearly see what they are to learn, what they already know or expected from this, and what is unexpected for them and contradicts their knowledge. Upon being presented the training material (lecture on this topic, the text of the paragraph), the pupils will need to return to these statements and evaluate their accuracy using the information received at the lesson (the reflection stage).

The second stage, Comprehension stage, is associated with receiving new information (from a teacher's lecture, textbook, educational film, etc.), which must be comprehended and correlated with the existing knowledge. At this stage, the pupils guided by the teachers answer those questions that they posed to themselves earlier, independently tracking the process of cognition and their own understanding. During the lesson, the pupils learn to actively manage information, separating the main points from the secondary ones, combining new knowledge with that previously acquired.

An effective technique used in teaching humanities is the Bloom Cube. This technique can be used at Russian lessons as a kind of control over the pupils' cognitive activities. The Bloom Cube helps to formulate a task in accordance with a problem set. Questions are put on the face of a geometric figure, requiring the student to consider all aspects of the topic being studied ("What ...", "Why ...”, “ Explain ...”, "Suggest ...”, “Come up with ...”, "Share ...”). The pupils can be offered several options for this kind of task, aimed at consolidating new training material. This, for example, can be the filling one of the Bloom Cubes concerning the 
Synonyms topic: "What is the most important condition for synonymous words", "Why would our speech be monotonous without synonyms?", "Explain how contextual synonyms differ from common ones", "Suggest examples of absolute synonyms", "Think of several sentences with synonyms that have different uses or different stylistic colors", "Share interesting facts about synonyms, that became known to you thanks to the note from the History of Language."

The third stage, Reflection, involves generalization and assimilation of the information received, the formation of each pupil's personal attitude to the material being studied, and identification of what is still unknown. This stage is characterized by putting knowledge into practice, generalizing new ideas and concepts, rethinking the pupils' own ideas while taking into account newly acquired knowledge.

An excellent example of critical thinking technology application at the Reflection stage can be the use of the cinquain, aimed at the synthesis, analysis, and generalization of the material studied. The pupils are invited to write a poem consisting of five lines, on the topic studied at the lesson. The poem should be built according to a certain model: line 1 - the subject of the cinquain, expressed in one word, usually a noun; line 2 - description of the subject using two adjectives (participles), line 3 - the description of the action within the said subject in three words, usually verbs; line 4 is a four-word phrase expressing the author's attitude to this subject; line 5 is a single word, synonymous to the first one, the emotionally figurative or philosophically generalized level which repeats the essence of the subject. Thus, for example, studying synonyms, students can show their personal knowledge of the study object using the cinquain: "Synonyms // Clarifying, embellishing // Replace, specify, enrich // Make speech bright and accurate // Richness". So, the laconicism of the cinquain presentation form develops the ability to summarize information, transform and interpret it, express an idea in several meaningful words, succinct and concise expressions, and contributes to the actualization and development of the pupils' creative abilities.

\section{Conclusions}

Summing up what has been said, the critical thinking development technology is implemented through the interactive inclusion of students in the educational space through a specific organization of the educational process based on three main stages and a system of teaching methods that consistently implement the tasks at each stage.

The use of the critical thinking technology in secondary school contributes to the formation and development of cognitive interests and abilities of pupils and the activation of 
their independent search and creative activity. This technology develops the pupils' mental and speech activity and contributes to their active involvement in the educational and cognitive process.

ACKNOWLEDGEMENTS: The work is performed according to the Russian Government Program of Competitive Growth of Kazan Federal University.

\section{REFERENCES}

BELOZERTSEV, E. P.; CHERNYKH, L. A. The idea and principle of nationality in education: a monograph. 2003.

BOCHINA, T.; AGEEVA, J.; VLASICHEVA, V. Multimedia presentation as a strategy of teaching speaking. In: INTERNATIONAL TECHNOLOGY, EDUCATION AND DEVELOPMENT CONFERENCE, 8., 2014, Valencia. Proceedings [...]. Valencia, Spain: INTED, 2014. p. 7661-7669.

EROFEEVA, A. A. et al. Actividad comunicativa y formación de la cultura del habla en los estudiantes. Dilemas contemporáneos: Educación, Política y Valores, año VI, 2019.

GALITSKY, E.O. Dialogue in education as a way of becoming tolerance. 2004.

NIKIFOROVA, E. P.; BORISOVA, L .P.; EVERSTOVA, A. I. The use of critical thinking technology in the lessons of the Russian language in the Yakut school. Historical and socioeducational thought, v. 9, n. 4/2, p. 169-176, 2017.

NURULLINA, G.M.; EROFEEVA, I.V.; USMANOVA, L.A. Organization of extracurricular activity in the system of teacher professional training. The European Proceedings of Social \& Behavioural Sciences, n. 36, p. 310-316, 2018.

SHKURKO, V. Y.; LUKOYANOVA, Y. K.; SERGEEVA, E. Using Fictional Texts In Teaching Russian As A Second Native Language. Modern Journal Of Language Teaching Methods, v. 7, n. 10, p. 59-63. 2017.

SORINA, G. V. Critical thinking: history and current status. Bulletin of Moscow University, v. 7, n. 6, p. 97-110. 2003.

ZAGASHEV, I. O.; ZAIRE-BEK, S. I. Critical thinking: technology development. 2003. 


\section{How to reference this article}

SHTYRLINA, E. G.; KAZANTSEVA, A. M.; HASAN, I. Critical thinking development technology: theoretical basics and application in secondary school (on the example of teaching the russian language). Revista Ibero-Americana de Estudos em Educação, Araraquara, v. 7, n. esp. 1, p. 31-38, fev. 2021. e-ISSN: 2447-3529. DOI: https://doi.org/10.29051/el.v7iEsp1.14856

Submitted: $28 / 10 / 2020$

Required revisions: $19 / 12 / 2020$

Approved: $13 / 01 / 2021$

Published: 28/02/2021 